\title{
The effects of posterior pericardiotomy on pericardial effusion, tamponade, and atrial fibrillation after coronary artery surgery
}

\author{
Mehmet Kaya ${ }^{1}$, Taner İyigün ${ }^{1}$, Pınar Yazıcı ${ }^{1}$, Yasin Melek ${ }^{1}$, Safa Göde ${ }^{1}$, Salih Güler ${ }^{1}$, Mehmet Karaçalılar ${ }^{1}$, \\ Muhammet Hulusi Satılmışoğlu², Ersin Erek ${ }^{1}$
}

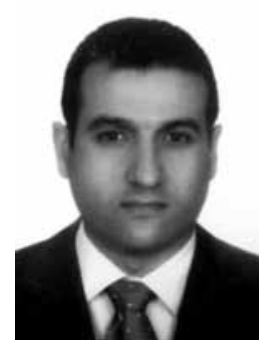

\author{
${ }^{1}$ Department of Cardiovascular Surgery, Istanbul Mehmet Akif Ersoy Thoracic and Cardiovascular Surgery Training \\ and Research Hospital, Istanbul, Turkey \\ 2Department of Cardiology, Istanbul Mehmet Akif Ersoy Thoracic and Cardiovascular Surgery Training and Research Hospital, \\ Istanbul, Turkey
}

Kardiochirurgia i Torakochirurgia Polska 2014; 11 (2): 113-118

\begin{abstract}
Introduction: Pericardial effusion and atrial fibrillation occur commonly after coronary artery surgery.

Aim of the study: A prospective randomized clinical trial was conducted to evaluate the effects of posterior pericardiotomy on the occurrence of pericardial effusion, tamponade, and atrial fibrillation.

Material and methods: The study group consisted of 96 patients (77 male and 19 female) at a mean age of $58.1 \pm 9.8$ years. The patients were randomly assigned to one of three study groups: patients undergoing posterior pericardiotomy (group I, $n=30$ ), controls (group II, $n=33$ ), and patients with additional posterior pericardial drainage tubes $(28 \mathrm{~mm})$ who did not undergo posterior pericardiotomy (group III, $n=33$ ). Results: Postoperative hospitalization ( $p=0.03 ; 11.56 \pm 10.64$ ) and reoperation due to tamponade $(p=0.019 ; 12.1 \%)$ were significantly higher in group II. Extensive pericardial effusions were detected in one patient on the first postoperative day (group II, $n=1$ ), in one patient on the fifth postoperative day (group III, $n=1$ ), and in one patient on the $30^{\text {th }}$ day after the operation (group III, $n=1$ ). Pericardial effusion exhibited regression in group I on postoperative day $30(p=0.028)$. A higher rate of postoperative atrial fibrillation was noted in group I, but no significant differences were found between the groups with regard to postoperative atrial fibrillation.

Conclusions: Patients who did not undergo posterior pericardiotomy or did not receive posterior chest tubes exhibited residual pericardial effusion, required longer hospitalization, and had to be reoperated due to tamponade. Both posterior pericardiotomy and the use of posterior tubes are effective in the early postoperative period.

Key words: posterior pericardiotomy, pericardial effusion, cardiac tamponade, atrial fibrillation.
\end{abstract}

\section{Streszczenie}

Wstęp: Wysięk osierdziowy i migotanie przedsionków to często występujące powikłania po operacjach tętnic wieńcowych. Cel pracy: W celu oceny wpływu perikardiotomii tylnej na występowanie wysięku osierdziowego, tamponady oraz migotania przedsionków przeprowadzono prospektywne badanie kliniczne z randomizacją.

Materiał i metody: Badana grupa składała się z 96 pacjentów (77 mężczyzn i 19 kobiet) w wieku średnio 58,1 \pm 9,8 roku. Pacjenci zostali losowo przydzieleni do jednej z trzech grup: grupy pacjentów poddanych perikardiotomii tylnej (grupa I, $n=30$ ), grupy kontrolnej (grupa II, $n=33$ ) oraz pacjentów, u których zastosowano tylny drenaż osierdziowy, którzy jednak nie zostali poddani zabiegowi perikardiotomii tylnej (grupa III, $n=33$ )

Wyniki: Czas trwania hospitalizacji pooperacyjnej ( $p=0,03$; $11,56 \pm 10,64)$ oraz częstość reoperacji z powodu tamponady ( $p=0,019 ; 12,1 \%$ ) były znacząco wyższe $\mathrm{w}$ grupie II. Znaczny wysięk osierdziowy wykryto $u$ jednego pacjenta (grupa II, $n=1)$ w pierwszym dniu po operacji, $u$ jednego pacjenta w piątym dniu po operacji (grupa III, $n=1$ ) oraz $u$ jednego pacjenta W 30. dniu po operacji (grupa III, $n=1$ ). W 30. dniu po operacji $(p=0,028)$ w grupie I odnotowano regresję wysięku osierdziowego. W grupie I stwierdzono również wyższy współczynnik pooperacyjnego migotania przedsionków, jednakże w tym względzie między grupami nie było znaczących różnic.

Wnioski: Pacjenci, którzy nie zostali poddani perikardiotomii tylnej lub u których nie zastosowano tylnego drenażu klatki piersiowej, wykazywali szczątkowy wysięk osierdziowy, wymagali dłuższej hospitalizacji i musieli być ponownie operowani z powodu tamponady. Zarówno perikardiotomia tylna, jak i tylny drenaż klatki piersiowej okazały się skuteczne we wczesnym okresie pooperacyjnym.

Słowa kluczowe: perikardiotomia tylna, wysięk osierdziowy, tamponada serca, migotanie przedsionków.

Address for correspondence: Mehmet Kaya, MD, Istanbul Mehmet Akif Ersoy, Thoracic and Cardiovascular Surgery Training and Research Hospital, Kucukcekmece, Istanbul, Turkey, tel. +90 212 6922000, fax +90 212 4719494, e-mail: drmehmetkaya@gmail.com 


\section{Introduction}

Pericardial effusion, which is a common complication after coronary artery surgery (CAS), may be the cause of significant morbidity. It occurs in about $30 \%$ of patients who undergo CAS [1]. It is often benign and small in volume, but can lead to life-threatening events, such as cardiac tamponade [2]. Delayed postoperative cardiac tamponade following an open-heart operation is an infrequent, but potentially serious complication. Although previous reports have dealt with the clinical features and management of this problem, an optimal approach to prevent postoperative pericardial effusion and related problems has not been clearly defined $[3,5]$.

This study aims to investigate the effects of posterior pericardiotomy (PP) on the development of pericardial effusion, tamponade, and atrial fibrillation following CAS.

\section{Material and methods}

This prospective randomized case-controlled study was carried out on 96 patients (77 men and 19 women; age: 35-78 years; mean: 58.1 years). The patients, undergoing CAS performed by the same surgical team between March 2012 and January 2013 in Istanbul Mehmet Akif Ersoy Thoracic and Cardiovascular Surgery Research and Training Hospital, were assigned to 3 groups. After the study had received the approval of the Institutional Review Board, informed consent was obtained from all patients. A random number table was used for simple case randomization. The treatment was carried out blinded. The treating physician did not know the groups to which individual patients had been assigned. Patients with renal failure, hyperthyroidism, emergency CAS, history of cardiac operations associated with valvular heart disease, low ejection fraction (<35\%), and preoperative atrial fibrillation or other rhythm disorders, as well as patients who did not provide research authorization, were excluded from the study.

The study groups included patients after PP (group I, $n=30$ ), a control group (group II, $n=33$ ), and patients without PP who received posterior pericardial tubes (the tube was placed behind the heart and sutured to the adjacent pericardial tissue to avoid tube-induced ventricular arrhythmias) (group III, $n=33$ ). Anesthetic medication, cardiopulmonary bypass, and surgical techniques were similar in all groups. Antegrade intermittent tepid blood cardioplegia was used in all patients. Systemic hypothermia $\left(32^{\circ} \mathrm{C}\right)$ and hemodilution were applied. In group I, a 4-cm longitudinal incision was made parallel and posterior to the left phrenic nerve, extending from the left inferior pulmonary vein to the diaphragm, as described by Mulay et al. [6]. In group I, the relationship between the location of the distal part of circumflex anastomosis and PP was also carefully considered. All PPs were performed under cardiopulmonary bypass after proximal anastomoses were established. Moreover, all patients underwent pleurotomy and lateral pericardiotomy (approximately $3.5-4.5 \mathrm{~cm}$ in size) in which the internal thoracic artery (ITA) was used for anastomosis and positioned medially to the lung, which allowed the ITA to run without kinking or twisting. The inferior part of the pericardium was left open $(2 \mathrm{~cm})$ in our study. A straight tube was placed in the anterior mediastinum and an angled tube was placed in the left hemithorax in all patients. The left pleural cavity was routinely opened. The same postoperative pain management protocol was provided for all patients. After a routine closure of the chest, drains were frequently milked and stripped to ensure tube patency during the intensive care unit stay. Low-intermittent suction was also applied. The chest tubes were removed on the $2^{\text {nd }}$ postoperative day when the drainage became serous; otherwise, they remained in use for one or more days.

Pericardial effusion was defined as the accumulation of fluid in the pericardial space determined by transthoracic echocardiography (TTE). The presence of pericardial effusion on 2-dimensional TTE was assessed using the criteria previously described by Bakhshandeh et al. [7]. Two-dimensional echocardiography was performed on postoperative days 1 and 5, as well as 1 month after surgery. The maximum diastolic separation between the pericardium and epicardium was measured at the tip of the mitral valve leaflet. When the diastolic echo-free space between the left ventricular posterior wall and the pericardium was < $10 \mathrm{~mm}$, the pericardial effusion was classified as small. When the space was $10-20 \mathrm{~mm}$, the effusion was classified as moderate, while for spaces $>20 \mathrm{~mm}$, the effusion was classified as severe. If the diagnosis of evident pericardial effusion (moderate or severe) was established, TTE was performed daily, and the volume of the effusion was observed closely.

We compared the groups with regard to the volume of effusion on postoperative days 1, 5, and 30. In addition, each group was evaluated separately for the progression of pericardial effusion.

Cardiac tamponade was defined by clinical signs and symptoms in addition to echocardiographic criteria. Patients with no or small pericardial effusion and an uneventful postoperative course were discharged from the hospital on postoperative day 5. Patients with moderate or severe pericardial effusion underwent daily echocardiographic examinations. Patients with moderate and severe pericardial effusion were treated with non-steroidal anti-inflammatory drugs. During hospitalization, all patients were continuously monitored with the use of a portable electrocardiogram (ECG, telemetry) to detect atrial fibrillation. Atrial fibrillation was considered to be persistent and clinically significant when it lasted for more than 5 min. Intravenous amiodarone was used to treat patients with AF.

Statistical analysis was performed with the NCSS (Number Cruncher Statistical System) 2007 Statistical Software (Utah, USA). One-way ANOVA and Tukey HSD tests were used for the statistical analysis of the groups' parameters. Subgroup analysis was performed according to the results of TTE. The differences were also analyzed using $\chi^{2}$ tests and independent $t$-tests where applicable. Clinical data were expressed as mean \pm SD. A $p$ value $<0.05$ was considered statistically significant. 


\section{Results}

The hospital mortality in the study was $2 \%(n=2)$; both patients were in group II. One of these patients experienced low cardiac output during and following reoperation due to cardiac tamponade and died on postoperative day 12. The other patient had an uneventful postoperative course, but was readmitted to the hospital on postoperative day 11 due to cardiac tamponade and acute kidney failure. Pericardial drainage was performed, but the patient died of sepsis on postoperative day 45.

The groups did not differ in terms of demographic parameters, which are summarized in Table I. The average total volume of drainage (mediastinal and thoracic) during the first 24 hours was similar in all groups $(536.67 \pm 237.873 \mathrm{cc}$, $656.97 \pm 407.634 \mathrm{cc}$, and $577.27 \pm 374.349 \mathrm{cc}$, respectively; $p=0.383$ ) (Table II). In group I, the volume of the fluid evacuated by mediastinal drainage was lower than in groups II and III, but the difference was not statistically significant (Table II). Two patients in group II required reoperation due to excessive mediastinal hemorrhage and cardiac tamponade. Echocardiographic evaluation demonstrated moderate to severe posterior and lateral pericardial effusions in these patients. The remaining patients underwent resternotomy. The incidence of cardiac tamponade was higher in group II ( $n=4,12 \%)$, and the differences between the groups were statistically significant $(p=0.019)$. Two of the patients with pericardial tamponade were managed by subxiphoid pericardial drainage alone; 400 to $1000 \mathrm{~mL}$ of fluid was removed. Two patients in group III were reoperated due to excessive hemorrhage in the early postoperative period.

The average volume of pericardial effusion significantly decreased with time in groups I and II (Fig. 1). No regression was detected in group III. Approximately $50 \%$ of the patients had small pericardial effusion on the first posto-

Tab. I. Demographic variables in groups

\begin{tabular}{|c|c|c|c|c|c|c|c|c|}
\hline Factors & & \multicolumn{2}{|c|}{ Group I } & \multicolumn{2}{|c|}{ Group II } & \multicolumn{2}{|c|}{ Group III } & $p$ \\
\hline Age & & \multicolumn{2}{|c|}{$56.9 \pm 10.13$} & \multicolumn{2}{|c|}{$58.91 \pm 10.90$} & \multicolumn{2}{|c|}{$58.58 \pm 7.62$} & 0.680 \\
\hline \multirow{2}{*}{ Sex } & Male & 23 & $76.67 \%$ & 29 & $87.88 \%$ & 25 & $75.76 \%$ & \multirow{2}{*}{0.392} \\
\hline & Female & 7 & $23.33 \%$ & 4 & $12.12 \%$ & 8 & $24.24 \%$ & \\
\hline BMI & & \multicolumn{2}{|c|}{$28.11 \pm 5.16$} & \multicolumn{2}{|c|}{$27.18 \pm 4.28$} & \multicolumn{2}{|c|}{$27.68 \pm 3.47$} & 0.695 \\
\hline Family history, $n$ & & 11 & $36.67 \%$ & 6 & $18.18 \%$ & 15 & $45.45 \%$ & 0.057 \\
\hline COPD, $n$ & & 10 & $33.33 \%$ & 7 & $21.21 \%$ & 15 & $45.45 \%$ & 0.113 \\
\hline $\mathrm{DM}, n$ & & 16 & $53.33 \%$ & 12 & $36.36 \%$ & 20 & $60.61 \%$ & 0.131 \\
\hline $\mathrm{HT}, n$ & & 15 & $50.00 \%$ & 18 & $54.55 \%$ & 23 & $69.70 \%$ & 0.246 \\
\hline History of smoking, $n$ & & 19 & $63.33 \%$ & 20 & $60.61 \%$ & 22 & $66.67 \%$ & 0.877 \\
\hline EF value & & & $54 \pm 10.78$ & & $52.88 \pm 9.79$ & & $52.58 \pm 8.30$ & 0.829 \\
\hline \multirow{5}{*}{ Number of distal bypasses } & 1 & 2 & $6.67 \%$ & 2 & $6.06 \%$ & 1 & $3.03 \%$ & \multirow{5}{*}{0.054} \\
\hline & 2 & 4 & $13.33 \%$ & 7 & $21.21 \%$ & 5 & $15.15 \%$ & \\
\hline & 3 & 12 & $40.00 \%$ & 13 & $39.39 \%$ & 15 & $45.45 \%$ & \\
\hline & 4 & 5 & $16.67 \%$ & 11 & $33.33 \%$ & 11 & $33.33 \%$ & \\
\hline & 5 & 7 & $23.33 \%$ & 0 & $0.00 \%$ & 1 & $3.03 \%$ & \\
\hline Mortality, $n$ & & 0 & $0.00 \%$ & 2 & $6.06 \%$ & 0 & $0.00 \%$ & 0.142 \\
\hline Bleeding-related revision, $n$ & & 0 & $0.00 \%$ & 2 & $6.10 \%$ & 2 & $6.10 \%$ & 0.387 \\
\hline Tamponade, $n$ & & 0 & $0.00 \%$ & 4 & $12.10 \%$ & 0 & $0.00 \%$ & 0.019 \\
\hline Postoperative pneumonia, $n$ & & 4 & $13.33 \%$ & 12 & $36.36 \%$ & 10 & $30.30 \%$ & 0.106 \\
\hline Postoperative AF, $n$ & & 6 & $20.00 \%$ & 11 & $33.33 \%$ & 7 & $21.21 \%$ & 0.392 \\
\hline Postoperative CVA, $n$ & & 1 & $3.33 \%$ & 2 & $6.06 \%$ & 0 & $0.00 \%$ & 0.366 \\
\hline Postoperative kidney failure, $n$ & & 3 & $10.00 \%$ & 4 & $12.12 \%$ & 3 & $9.09 \%$ & 0.918 \\
\hline Cross-clamp time, minutes & & \multicolumn{2}{|c|}{$43.47 \pm 15.67$} & \multicolumn{2}{|c|}{$45.79 \pm 21.19$} & \multicolumn{2}{|c|}{$43.39 \pm 14.68$} & 0.821 \\
\hline CPB time, minutes & & \multicolumn{2}{|c|}{$79.6 \pm 26.08$} & \multicolumn{2}{|c|}{$86.24 \pm 27.33$} & \multicolumn{2}{|c|}{$81.79 \pm 21.35$} & 0.560 \\
\hline Units of RBCs & & \multicolumn{2}{|c|}{$2.4 \pm 2.03$} & \multicolumn{2}{|c|}{$3.82 \pm 3.70$} & \multicolumn{2}{|c|}{$2.73 \pm 3.02$} & 0.150 \\
\hline Hospitalization time, days & & \multicolumn{2}{|c|}{$6.63 \pm 2.71$} & \multicolumn{2}{|c|}{$11.56 \pm 10.64$} & \multicolumn{2}{|c|}{$8.61 \pm 5.96$} & 0.030 \\
\hline EuroSCORE & & \multicolumn{2}{|c|}{$1.48 \pm 1.16$} & \multicolumn{2}{|c|}{$1.24 \pm 0.67$} & \multicolumn{2}{|c|}{$1.89 \pm 2.04$} & 0.175 \\
\hline
\end{tabular}


Tab. II. Differential drainage volume from each chest tube

\begin{tabular}{|c|c|c|c|c|c|c|c|c|}
\hline Group & Total blood loss & $p$ & $\begin{array}{l}\text { Mediastinal } \\
\text { drainage tube }\end{array}$ & $\begin{array}{l}\text { Pericardial } \\
\text { drainage tube }\end{array}$ & $\begin{array}{l}\text { Total mediastinal } \\
\text { drainage volume* }\end{array}$ & $p$ & $\begin{array}{l}\text { Thoracic drainage } \\
\text { tube }\end{array}$ & $p$ \\
\hline I & $536.67 \pm 237.873$ & \multirow{3}{*}{0.383} & $200 \pm 118.722$ & - & $200 \pm 118.722$ & \multirow{3}{*}{0.085} & $340 \pm 165.258$ & \multirow{3}{*}{0.711} \\
\hline II & $656.97 \pm 407.634$ & & $287.66 \pm 186.188$ & - & $287.66 \pm 186.188$ & & $346.09 \pm 215.910$ & \\
\hline III & $577.27 \pm 374.349$ & & $133.33 \pm 85.847$ & $142.42 \pm 81.606$ & $272.73 \pm 164.098$ & & $304.55 \pm 259.541$ & \\
\hline
\end{tabular}

${ }^{\star}$ The volume of pericardial drainage was added to the volume of mediastinal drainage for group III.

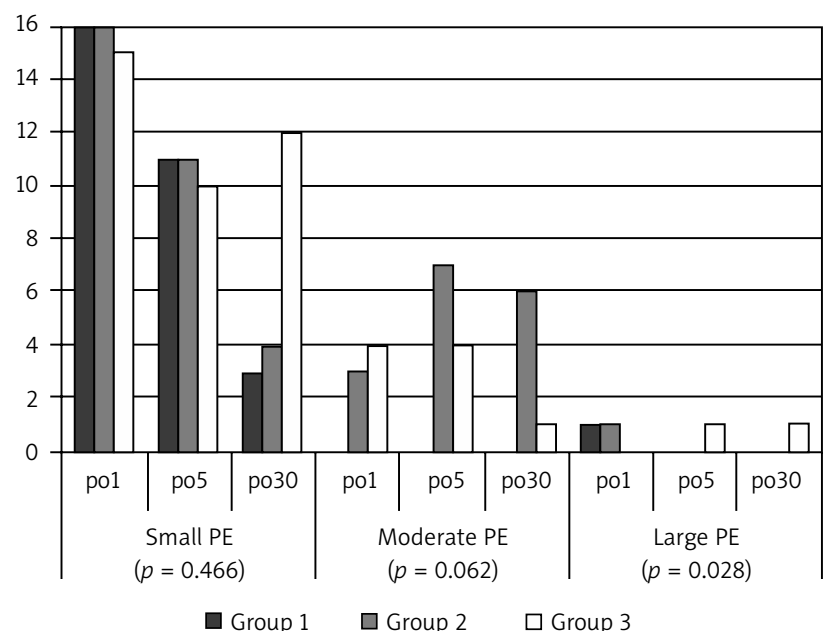

Fig. 1. Comparison of the groups with regard to the volume of pericardial effusion

perative day; no difference between the groups was found. Moderate pericardial effusion was detected in 8 patients (group I, $n=1$; group II, $n=3$; group III, $n=4$ ) on the first postoperative day, in 11 patients (group II, $n=7$; group III, $n=4$ ) on the fifth postoperative day, and in 7 patients on the $30^{\text {th }}$ postoperative day (group II, $n=6$; group III, $n=1$ ) during the study period. Severe pericardial effusion was detected in one patient (group II, $n=1$ ) on the first postoperative day, in one patient (group III, $n=1$ ) on the fifth postoperative day, and in one patient (group III, $n=1$ ) on the $30^{\text {th }}$ postoperative day. The incidence of moderate to severe pericardial effusion in group I was significantly lower than in the other groups on the $30^{\text {th }}$ postoperative day $(n=0$, $p=0.028$ ). Figure 1 shows a comparison of the groups with regard to the volume of pericardial effusion. Seven patients underwent reoperation. Four of these patients (group II, $n=4$ ) underwent drainage of severe pericardial effusion on postoperative days $0,1,11$, and 17; one patient (group II) underwent sternal dehiscence repair. None of the patients in group I required any intervention for pericardial effusions.

Atrial fibrillation was detected in 24 of the 96 patients (25\%: 6 patients in group I, 11 patients in group II, 7 patients in group III). No statistically significant difference between the groups $(p=0.392)$ was present in this respect.

The length of hospital stay was significantly shorter in group I $(6.63 \pm 2.71, p=0.03)$.

\section{Discussion}

There are a number of articles favoring the use of posterior pericardiotomy, but no comprehensive comparison has been conducted between the use of a pericardial tube and PP in patients undergoing CAS. Pericardial effusion and the associated complications are common after all kinds of cardiac surgery due to postoperative bleeding or postcardiotomy syndrome [8]. However, clinically significant pericardial effusion occurs rarely and can be a crucial risk factor for cardiac tamponade (1\%) [9]. It is also an important cause of morbidity [10, 11]. Many clinical approaches have been proposed to prevent postoperative pericardial effusion/tamponade. One of those methods is PP. Posterior pericardiotomy has been reported to reduce the prevalence of pericardial effusion from $40 \%$ to $8 \%$ with a simultaneous reduction in the prevalence of SVT (supraventricular tachycardia) [8].

Pericardial and thoracic collection is mostly drained via chest tubes. In intensive care, the semi-sitting position helps thoracic drainage in the early postoperative period by supporting the patient's back. Despite all the abovementioned measures, the posterior wall of the pericardial sac forms an unprotected space that may cause pericardial effusion to develop septae. This leads to the appearance of adhesions preventing blood drainage, leading to cardiac compression. Moreover, the collection of fluid may persist due to bleeding resulting from the use of anticoagulants [12]. In fact, anti-coagulants (low-molecular-weight heparin) were used postoperatively in our patients with atrial fibrillation. Posterior pericardial effusion can be evacuated by placing a tube in the posterior pericardial space. The placement of the pericardial tube is simple to perform, but it may have certain drawbacks. The tube may come into contact with coronary grafts during cardiac activity or movement. Tube displacement may induce arrhythmia and compression of the grafts. However, the patients included in the study (in group III as well as the other groups) did not exhibit any arrhythmias (apart from AF) or ischemic changes. This may be due to the fact that we fixed the pericardial tube to the surface of the diaphragmatic pericardium with polypropylene.

Multiple comparisons of the mediastinal cavity drainage volume showed similarities between all groups. Group I, however, had lower mediastinal drainage than the remaining groups. PP or the use of posterior tubes may lessen the volume of pericardial effusion after CAS. Moreover, patients in group I exhibited regression of pericardial effusion during 30 postoperative days. This regression was statistically significant when compared to the other groups. This proved that PP had a lasting effect on pericardial effusion, as presented by Figure 1. What stands out in our results 
is that pericardial effusion may occur if no intervention is performed on the posterior part of the pericardium. For this reason, we recommend PP or retrocardiac tube placement.

This technique is suggested in both CAS and valve surgery, but it is not routinely used $[13,14]$. What is more, PP is recommended by the American College of Chest Physicians Guidelines and by some authors as a preventive technique for postoperative atrial fibrillation $[15,16]$. Several studies have emphasized the high mortality rates associated with delayed treatment [17]. Supraventricular tachyarrhythmias, mainly in the form of atrial fibrillation, occur in up to $40 \%$ of patients undergoing CAS [4]. Although AF is usually benign, it can cause hemodynamic instability, prolonged hospital stay, and increased cost and, in rare cases, predispose to cerebrovascular accidents [18]. The antiarrhythmic effect of PP may, however, be a theoretical issue [19], as we observed similar results regarding atrial fibrillation in all the groups. In fact, the results of our study were different than expected with regard to atrial fibrillation compared to other researchers $[4,6,16]$. Additionally, Asimakopoulos et al. also found that the prevalence of atrial fibrillation was not significantly reduced $(20 \%)$ in comparison to the conventional technique (26\%) [21].

Another issue is that humans have increasingly longer life spans [20], which may result in higher numbers of reoperations. Ellman et al. found that patent coronary grafts were the most commonly injured structures during reoperation (46\%) [22]. Thus, the importance of covering the aorta and grafts should be emphasized. Protecting the back side of the heart against adhesions is also important. We routinely cover the aorta and proximal anastomoses of grafts with thymic fat tissue and the anterior wall of the pericardial cavity. We also place an anterior mediastinal tube over the thymic fat tissue before closing the sternum in all patients. Behind the heart, adhesions between the inferior surface of the heart and the diaphragm can cause difficulties when dissecting the tissue layers during reoperation. Mulay et al. demonstrated that PP provides an effective drainage pathway from the left pleural cavity, thereby reducing the prevalence of pericardial effusion [6]. For this reason, PP may be advantageous for reoperated patients in terms of reducing adhesions related to pericardial effusion.

Echocardiography can be useful in confirming and identifying the presence of pericardial effusion, hematoma, and tamponade [23]. According to the results of our study, it is important to diagnose pericardial effusion at an early stage. Hemodynamic deterioration due to pericardial fluid can be divided into four stages: pericardial fluid, hemodynamic tamponade, echocardiographic tamponade, clinical tamponade [23].

The duration of hospital stay was significantly shorter in the PP group. Echocardiographic follow-up of patients with pericardial effusion might be a factor extending the duration of hospital stay. We recommend the PP technique and routine echocardiographic monitoring during the postoperative period in patients undergoing CAS.
There is not sufficient research regarding the effects of PP on long-term results [24]. The present study also demonstrated that patients undergoing PP required a significantly shorter hospital stay and experienced lower rates of pericardial effusion and cardiac tamponade than the other groups.

\section{Limitations}

This research was carried out on a small set of patients ( $n=96)$; therefore, there was an imbalance between men and women enrolled in this trial. Atrial fibrillation was revealed in $20-33 \%$ of patients in this series. The patients were given postoperative anti-coagulants for arrhythmias. Group II had a 2-fold elevation in the number of patients going into AF postoperatively. This could have influenced the rate of tamponade and pericardial effusion in the study.

\section{Conclusions}

In conclusion, PP may be a useful technique in the prevention of pericardial effusion and cardiac tamponade after CAS because it is simple, safe, and effective. Furthermore, it might reduce hospital stay by preventing complications, as mentioned above.

Both PP and the use of posterior tubes are effective in the early postoperative period.

Oral presentation at the $22^{\text {nd }}$ Annual Meeting of the Asian Society for Cardiovascular and Thoracic Surgery that will be held in Istanbul on April 3-6, 2014.

\section{Acknowledgements}

We wish to express our thanks to Gülbeyaz Sevin Özgül (MD) and Mugisha Kyaruzi (MD) for their assistance in the writing of this article.

\section{Disclosure}

Authors report no conflicts of interest.

\section{References}

1. Cakalagaoglu C, Koksal C, Baysal A, Alıcı G, Ozkan B, Boyacioglu K, Tasar M, Atasoy EB, Erdem H, Esen AM, Alp M. The use of posterior pericardiotomy technique to prevent postoperative pericardial effusion in cardiac surgery. Heart Surg Forum 2012; 15: 84-89.

2. Chuttani K, Pandian NG, Mohanty PK, Rosenfield K, Schwartz SL, Udelson JE, Simonetti J, Kusay BS, Caldeira ME. Left ventricular diastolic collapse. An echocardiographic sign of regional cardiac tamponade. Circulation 1991; 83: 1999-2006.

3. Curzen N, Poole-Wilson P. Atrial tachyarrhythmias and coronary artery bypass surgery patient. Br J Cardiol 1994; 1: 57-59.

4. Kuralay E, Ozal E, Demirkili U, Tatar H. Effect of posterior pericardiotomy on postoperative supraventricular arrhythmias and late pericardial effusion (posterior pericardiotomy. J Thorac Cardiovasc Surg 1999; 118: 492-495.

5. Pires LA, Wagshal AB, Lancey R, Huang SK. Arrhythmias and conduction disturbances after coronary artery bypass graft surgery: epidemiology, management, and prognosis. Am Heart J 1995;129: 799-808.

6. Mulay A, Kirk AJ, Angelini GD, Wisheart JD, Hutter JA. Posterior pericardiotomy reduces the incidence of supra-ventricular arrhythmias following coronary artery bypass surgery. Eur J Cardiothorac Surg 1995; 9: 150-152.

7. Bakhshandeh AR, Salehi M, Radmehr H, Sattarzadeh R, Nasr AR, Sadeghpour $\mathrm{AH}$. Postoperative pericardial effusion and posterior pericardiotomy, related or not? Heart Surg Forum 2009; 12: 113-115. 
8. Radmehr H, Sattarzadeh R, Nasr AR, Sadeghpour AH. Postoperative pericardial effusion and posterior pericardiotomy: related? Bakhshandeh AR, Salehi M. Asian Cardiovasc Thorac Ann 2009; 17: 477-479.

9. Ashikhmina EA, Schaff HV, Sinak LJ, Li Z, Dearani JA, Suri RM, Park SJ, Orszulak TA, Sundt TM 3rd. Pericardial effusion after cardiac surgery: risk factors, patient profiles, and contemporary management. Ann Thorac Surg 2010; 89: 112-118.

10. Tsang TS, Barnes ME, Hayes SN, Freeman WK, Dearani JA, Butler SL, Seward JB. Clinical and echocardiographic characteristics of significant pericardial effusions following cardiothoracic surgery and outcomes of echo-guided pericardiocentesis for management: Mayo Clinic experience, 1979-1998. Chest 1999; 116: 322-331.

11. Sahni J, Ivert T, Herzfeld I, Brodin LA. Late cardiac tamponade after openheart surgery. Scand J Thorac Cardiovasc Surg 1991; 25: 63-68.

12. Erdil N, Nisanoglu V, Kosar F, Erdil FA, Cihan HB, Battaloglu B. Effect of posterior pericardiotomy on early and late pericardial effusion after valve replacement. J Card Surg 2005; 20: 257-260.

13. Erdil N, Nisanoglu V, Battaloglu B. Effectiveness of posterior pericardiotomy after valve replacement. J Card Surg 2006; 21: 638-639.

14. Creswell LL, Alexander JC Jr, Ferguson TB Jr, Lisbon A, Fleisher LA; American College of Chest. Intraoperative interventions: American College of Chest Physicians guidelines for the prevention and management of postoperative atrial fibrillation after cardiac surgery. Chest 2005; 128: 28-35.

15. Arbatli H, Demirsoy E, Aytekin S, Rizaoglu E, Unal M, Yagan N, Sonmez B. The role of posterior pericardiotomy on the incidence of atrial fibrillation after coronary revascularization. J Cardiovasc Surg (Torino) 2003; 44: 713-717.
16. Kaygin MA, Dag O, Güneş M, Senocak M, Limandal HK, Aslan U, Erkut B. Posterior pericardiotomy reduces the incidence of atrial fibrillation, pericardial effusion, and length of stay in hospital after coronary artery bypasses surgery. Tohoku J Exp Med 2011; 225: 103-108.

17. Susini G, Pepi M, Sisillo E, Bortone F, Salvi L, Barbier P, Fiorentini C. Percutaneous pericardiocentesis versus subxiphoid pericardiotomy in cardiac tamponade due to postoperative pericardial effusion. J Cardiothorac Vasc Anesth 1993; 7: 178-183.

18. Mostafa A, El-Haddad MA, Shenoy M, Tuliani T. Atrial fibrillation post cardiac bypass surgery. Avicenna J Med 2012; 2: 65-70.

19. Simpson IA, Munsch C, Smith EE, Parker DJ. Pericardial haemorrhage causing right atrial compression after cardiac surgery: role of transoesophageal echocardiography. Br Heart J 1991; 65: 355-356.

20. Zwoliński R, Jander S, Ostrowski S, Bartczak K, Adamek Kośmider A, Banyś A, Jaszewski R. Early and long term coronary artery bypass grafting outcomes in patients under 45 years of age. Kardiol Pol 2013; 71: 32-39.

21. Asimakopoulos G, Della Santa R, Taggart DP. Effects of posterior pericardiotomy on the incidence of atrial fibrillation and chest drainage after coronary revascularization: a prospective randomized trial. J Thorac Cardiovasc Surg 1997; 113: 797-799.

22. Ellman PI, Smith RL, Girotti ME, Thompson PW, Peeler BB, Kern JA, Kron IL. Cardiac injury during resternotomy does not affect perioperative mortality. J Am Coll Surg 2008; 206: 993-997.

23. Sagristà-Sauleda J, Mercé AS, Soler-Soler J. Diagnosis and management of pericardial effusion. World J Cardiol 2011; 3: 135-143.

24. Yorgancioğlu C, Farsak B, Tokmakoğlu H, Günaydin S. An unusual experience with posterior pericardiotomy. Eur J Cardiothorac Surg 2000; 18: 727-728. 